\title{
Erratum to: Civil War and Narrative
}

\author{
Karine Deslandes, Fabrice Mourlon \\ and Bruno Tribout
}

\section{Erratum to: \\ K. Deslandes et al. (eds.), Civil War and Narrative, https://doi.org/10.1007/978-3-319-61179-2}

In the original version of this book, the chapter "Oblivion or History: Two Different Ways of Coming Out of War" by Ninon Grangé was included in the back matter. It has now been moved into 'Part IV: Conclusion', and the erratum book has been updated with this change.

The updated online version of this book can be found at https://doi.org/10.1007/978-3-319-61179-2_13

https://doi.org/10.1007/978-3-319-61179-2

(C) The Author(s) 2018 https://doi.org/10.1007/978-3-319-61179-2_14 